\title{
Chronology of the Life and Works of Mark Twain
}

1835: Samuel Langhorne Clemens born two months premature in Florida, Missouri, on the Salt River, November 30, the sixth of seven children.

1839: Clemens family moves to Hannibal, Missouri, on the Mississippi River.

1847: John Marshall Clemens, Sam's father, dies March 24. 1849-1852: Apprenticed to Joseph P. Ament, editor of the Hannibal Courier, and subsequently to his older brother Orion Clemens, editor of the Western Union and Hannibal Journal. Writes earliest fiction for area newspapers and "The Dandy Frightening the Squatter" for the Boston Carpet-Bag.

1853-1854: Leaves home for St. Louis, New York City, and, Philadelphia, where he works as a journeyman printer. Visits Washington, D.C.

1855-1857: Lives and works in Keokuk, Iowa; St. Louis; and Cincinnati. In February of final year he meets Horace Bixby while traveling on the Mississippi River to New Orleans to sail for South America. Bixby agrees to make him an apprentice steamboat pilot for $\$ 500$.

1858-1861: Serves as a pilot on nineteen or twenty different steamboats operating between St. Louis and New Orleans. Younger brother Henry dies a week after a steamboat accident on June 13, 1858. When Civil War breaks up river commerce in June 1861, Clemens joins the Marion 
Rangers, a ragtag state militia that disbands after two weeks. Departs for Nevada Territory July 18 with brother Orion, who has been appointed by the Lincoln administration as secretary to the territorial governor. Arrives in Carson August 14. Becomes a silver and gold prospector. 1862: Joins the staff of the Virginia City Enterprise and writes "Petrified Man" and other unsigned items.

1863: Adopts the nom de guerre "Mark Twain," makes his first visit to San Francisco, meets Artemus Ward in Virginia City, and publishes "A Bloody Massacre near Carson," also known as the "Empire City Massacre Hoax."

1864: Elected "Governor of the Third House" by fellow journalists in Carson City, Nevada. Writes hoax suggesting that funds collected for Union soldiers went to a "Miscegenation Society" in the East. Moves permanently to San Francisco to avoid prosecution for challenging an editor from a competing newspaper to a duel resulting from his hoax. Writes for the San Francisco Morning Call and the Californian, where he meets fellow contributors Bret Harte, Charles Henry Webb, and Charles Warren Stoddard. Writes many of the sketches that would make up his first book, including "Aurelia's Unfortunate Young Man." Following a run-in with the police involving Steve Gillis, he relocates to Jim's Gillis's cabin in the mining town of Jackass Hill.

1865: Returns to San Francisco. Writes "Jim Smiley and His Jumping Frog," first published in the New York Saturday Press of November 18, 1865 .

1866: Visits Hawaii as a reporter for the Sacramento Union; lectures on the Sandwich Islands in California and Nevada; travels to New York via the Nicaragua Isthmus for the San Francisco Alta California.

1867: Lectures for the first time in New York City. Publishes The Celebrated Jumping Frog of Calaveras County, and Other Sketches; sails on the Quaker City for Europe and the Holy Land; returns from cruise in November. Meets Olivia Langdon (Livy) and her parents in New York City. 
1868: Visits Livy on New Year's Day. Travels in April to San Francisco to negotiate with the Alta California over book rights to the letters he wrote for newspaper publication from Europe and the Holy Land; finishes manuscript for The Innocents Abroad; lectures in California; courts Livy in Elmira, New York. Meets the Rev. Joseph H. Twichell, later a lifelong friend and fellow resident in Hartford, Connecticut. 1869: Becomes engaged to Livy Langdon; and purchases with help from his future father-in-law, Jervis Langdon, one-third interest in the Buffalo Express. Publishes The Innocents Abroad. Meets William Dean Howells in Boston.

1869-1870: Lecture tour with James Redpath Agency between November and January.

1870: Marries Livy February 2 and moves into furnished house in Buffalo purchased by her parents. Jervis Langdon dies of stomach cancer in August. Son Langdon Clemens born prematurely in November.

1871: Publishes Mark Twain's (Burlesque) Autobiography. Sells interest in Buffalo Express, moves to Hartford's Nook Farm, and rents home from Hooker family.

1872: Publishes Roughing It and Mark Twain's Sketches (London); lectures in England in the fall. First daughter, Olivia Susan Clemens (Susy), is born March 19. Only son, Langdon, dies June 2.

1873: Publishes The Gilded Age with Charles Dudley Warner. Lectures in London in the fall.

1874: Colonel Sellers, the play based on a character in The Gilded Age, opens in New York City. Publishes "A True Story" in the Atlantic Monthly. Publishes Mark Twain's Sketches (Hartford). Second daughter, Clara Langdon Clemens, is born June 8. Moves into his newly constructed home in Nook Farm.

1875: Publishes "Old Times of the Mississippi" in the Atlantic and Sketches, New and Old. 
1876: Writes 1601; writes Ah Sin with Bret Harte; publishes The Adventures of Tom Sawyer.

1877: Production of Ah Sin in Washington, D.C. Visits Bermuda with Joe Twichell. Delivers Whittier Birthday Dinner Speech in Boston. Markets "Mark Twain's Patent Self-Pasting Scrapbook." 1878: Publishes Punch, Brothers, Punch! 1878-1879: Lives in Germany, Italy, France, and England. 1880: Publishes A Tramp Abroad. Third daughter, Jane Lampton Clemens (Jean), born July 26. 1881: Meets George Washington Cable. Publishes The Prince and the Pauper.

1882: Travels down the Mississippi and visits New Orleans; returns upriver, stopping over in Hannibal on his way to St. Paul, and returns to New York and Hartford. Makes initial investment in the Paige Compositor. Writes "The Walt Whitman Controversy." 1883: Publishes Life on the Mississippi. 1884: Founds the Charles L. Webster Publishing Company. 1884-1885: Lecture tour with Cable. 1885: Publishes Adventures of Huckleberry Finn and Personal Memoirs of U.S. Grant.

1888: Publishes Mark Twain's Library of Humor; receives honorary master of arts degree from Yale.

1889: Publishes A Connecticut Yankee in King Arthur's Court. 1890: Mother Jane Lampton Clemens dies October 27. 1890-1891: Susy Clemens, preferring to use her first name, Olivia, with classmates, attends Bryn Mawr College.

1891: Family closes up Hartford house and sails to Europe. Twain stops further investments in the Paige Compositor. Arranges to write at least six travel letters from Europe for American newspaper publication. 
1892: Publishes Merry Tales and The American Claimant. Family resides in Berlin and later Florence.

1893: Befriended by robber baron Henry Huttleston Rogers, vice president of Standard Oil, Twain makes frequent trips back to United States to look after his interests in his flagging publishing company and the Paige Compositor, in which he still owns many shares.

1894: Charles L. Webster Publishing Company declares bankruptcy. Twain publishes Pudd'nhead Wilson.

1895: Abandons his interests in the Paige Typesetter. Publishes "Fenimore Cooper's Literary Offenses." Family returns to the United States and resides for the summer at Quarry Farm in Elmira.

1895-1896: Lecture tour to Australasia, which becomes the basis for Following the Equator (1897).

1896: Susy Clemens dies of spinal meningitis August 18. Family establishes residence in England. Jean Clemens diagnosed with epilepsy. Publishes Personal Recollections of Joan of Arc, as well as Tom Sawyer Abroad, Tom Sawyer, Detective, and Other Stories. Meets William James.

1897: Brother Orion Clemens dies December 11. Following the Equator published.

1897-1899: Establishes residence in Vienna so that Clara can study piano. Begins writing "Which Was the Dream?" "The Great Dark," and other dreamscapes.

1898: Pays off all debts related to Webster \& Company bankruptcy. Possibly meets Sigmund Freud in Vienna, then still working on The Interpretation of Dreams.

1898-1899: Works on the first two "Mysterious Stranger" drafts: "The Chronicle of Young Satan" and "Schoolhouse Hill."

1899: Publishes "Stirring Times in Austria," "Concerning the Jews," and "The Man That Corrupted Hadleyburg." 
1900: Moves to England and finally New York City, where the family rents 1o West 1oth Street. Publishes The Man That Corrupted Hadleyburg, and Other Stories and Essays.

1901: Publishes "To the Person Sitting in Darkness." Summers on Lake Saranac in the Adirondacks. Rents "baronial mansion" at Riverdale-on-the-Hudson.

1902: Visits Hannibal for the last time in conjunction with his going to the University of Missouri to accept an honorary Litt. D. degree. Summers at York Harbor, Maine, where Jean suffers two epileptic attacks. Livy suffers severe asthmatic attack and heart problems that prostrate her for six months. Isabel V. Lyon is hired as secretary. Jean contracts double pneumonia.

1902-1903: Works on "No. 44, The Mysterious Stranger." Summers in Elmira.

1903: Family returns to Riverdale; embarks for Florence in fall.

1904: Livy's health deteriorates. Works on "No. 44, The Mysterious Stranger." Sister-in-law Mollie Clemens dies January 15. Livy dies in Florence June 5. Family returns with body to Elmira. Sister Pamela dies August 31. Twain establishes residence at 21 Fifth Avenue, New York. 1905: Summers in Dublin, New Hampshire. Writes "3,000 Years among the Microbes" and "The War-Prayer." Publishes "King Leopold's Soliloquy."

1906: Publishes What Is Man? anonymously. Continues work on "No. 44." Appoints Albert Bigelow Paine as his official biographer. 1907: Visits Bermuda with Joe Twichell. Receives honorary Litt. D. degree from Oxford. Publishes Christian Science.

1908: Occupies "Stormfield" home in Redding, Connecticut, designed by John Howells. Nephew Samuel E. Moffett dies suddenly August 1. Suffers first attack of angina pectoris in August.

1909: Writes chapter 33 of "No. 44, The Mysterious Stranger." Publishes Is Shakespeare Dead? and Extract from Captain Stormfield's Visit to Heaven. Drafts "Letters from the Earth." Henry Rogers dies in May. Clemens 
suffers second attack of angina in June. Clara Clemens marries Ossip Gabrilowitsch at Stormfield October 6. Visits Bermuda with Paine in November and part of December. At Stormfield, daughter Jean Clemens dies in bathtub after an epileptic seizure on Christmas Eve.

1910: "Death of Jean" published in Harper's Monthly in January. Travels to Bermuda, falls ill, and returns in the company of Paine. Dies of heart failure April 21. Nina Clemens Gabrilowitsch, Twain's only grandchild, born August 18 .

1936: Ossip Gabrilowitsch dies September 14.

1944: Clara Gabrilowitsch marries Jacques Samossoud May 11.

1962: Clara Clemens Gabrilowitsch Samossoud dies November 19. 1966: Nina Clemens Gabrilowitsch dies January 16. 
This page intentionally left blank 